\section{Abstract}

Marine vessels are a combination of exterior styling and interior design. Styling arrangements create spaces by way of external form and also influence external form by compartmentalizing interior spaces and layout. The design works its way from the inside out as well as from the outside in Interior design layouts are based on the positions of masses and spaces on the outside. Exterior styling is dictated by the characteristics of specific typologies to be implemented. This paper proposes a model for sailing yachts that includes exterior styling and interior design layouts based on parameters. Most of the yacht geometry software has a three-dimensional view of the boat and shows it from in different angles on the screen. This software allows the form to be perceived in a better way compared to a hand-drawn design plane. The computer-aided software used in yacht design is especially useful for engineering calculations. There is no piece of software that automatically renders a digital deck and superstructure model. At this stage, the designer uses various add-ons to design the hull. There is a need for easily making changes on a rough model that will afford flexibility for the designer. When this model is created, it must include elements of the yacht typology of the design. Parameters to be used in parametric sailing yacht design are identified. A model can be developed by establishing the relationship between these parameters. The design process begins when the yacht hull model is imported into the program and modifications made on the model are simultaneously previewed as the variables are changed.

öz

Deniz araçlart stayling ve ic mekan tasarımlarının bir bütünüdür. Stayling oluşumu hem dış form aracılığıyla mekanı olusturmakta, hem de bölmelendirme ve beraberinde gelen iç mekan yerleşimleriyle dis formu etkilemektedir. Ikisi arasında bir ayrım yapılmadan hem içeriden dışarıya hem de dışarıdan içeriye doğru çalıșılmalıdır. İç mekandaki düzenlemeler diştaki doluluk ve boşluk

konumlandırllmasına bağlı olarak yapılmalıdır. Dış mekanda stayling ise özellikle bir tipoloji isteniyorsa, o tipolojinin özelliklerini de dikte etmektedir. Çalışma kapsamında yelkenli tipolojisinin stayling ve iç mekan çözümlemeleri birlikte yapllarak, bu bütünlüğü sağlayacak bir model önerisi yapılacaktır. İç mekan yerleşimlerinde en önemli husus olan bölmelendirme kavramı hem aracın su geçirmez bütünlüğünü koruyabilmesi için yapulan enine, yatay ve boyuna perdeler tasarlanması işlemi, hem de yaşam alanlarının düzenlenmesini içine alan bir kapsayıcılıkla kullanılmaktadır. Bu mekansal öğelerin tanımlanması ve birbirleriyle olan iliskilerinin ortaya konulmast ve tipolojinin gerekliliklerinin sayisal olarak belirlenmesiyle, ortaya bir model konulmustur. Böylece tasarımcilar için yön gösterici bir model elde edilmiş ve estetik değerlerin de eklenmesiyle tasarım

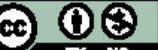

This work is licensed under a Creative Commons Attribution-NonConmencin 4.0 International License. \title{
Parametric Sailing Yacht Exterior and Interior Design
}

(D) Seval Özgel Felek Ordu Üniversitesi, Ünye Meslek Yüksek Okulu, Mimarlık ve Şehir Planlama Bölümü, Mimari Restorasyon Programı

Başvuru tarihi/Received: 20.05.2019, Kabul tarihi/Final Acceptance: 18.12.2019

\section{Introduction}

As vessels, yachts are primarily intended for having a good time. Even though their purpose is to have fun and engage in a hobby, yachts are stratified into categories. Sailing yachts could only run on sail power once; however, machine power became available after the Industrial Revolution. From then on, yachts have been classified into two main groups: sailing yachts and sailing motor yachts. While this classification is based on propulsion, it is possible to classify yachts according to the purpose of use, e.g. daily use, weekend, or long-distance yachts. They can also be classified as recreational yachts or racing yachts. This study deals with recreational yachts. The purpose of recreational yachts is to travel and see new places, benefit from the beauties of the sea and nature and enjoy yachting economically with minimal damage to nature. These yachts are not intended for competition with others or travelling quickly. Therefore, living comforts stand at the forefront. Average length of such vessels varies between 8 and 14 meters (Tokol, 2013, 23). According to Duman and Zengel (2016, 93-100), since the floating structures have a moving physical environment, the concepts of space and the psychological process in the space vary according to terrestrial structures and the yachts should be evaluated in terms of their spatial characteristics. This study examines yachts of this size manufactured by leading brands of the sector and identifies variables in order to parameterize superstructure and interior design. The size range of yachts has been expanded and examples between 8 and 18 meters have been examined.

\section{Parametricization of Superstructures and} Interiors of Sailing Yacht

\section{Hull Form}

The literature on computer-aided yacht design is concentrated around the discipline of engineering. Available resources on computer-aided yacht design in engineering are aimed at designing technical specifications of hull forms of yachts. "The Design Spiral for Computer Aided Boat Design" refers to the stages of the design spiral in the computer aided boat design. In the notes section of the study, it is stated that there is no general software for designing the hull and the interior at the same time and argued that this issue should be studied (Hollister, 1994). 'Computer Aided Yacht Design' is one of the pioneering works in this area (Foster, 1979). Some other studies titled as 'Numerical Investigation of a Systematic Model Series for Fast Monohulls' (Harries et al, 1997) and 'Parametric Design and Hydrodynamic Optimiza- 
tion of Ship Hull Forms' (Harries 1998), and 'Parametric Generation of Yacht Hulls' (Bole, 1997). 'Parametric Design of Sailing Hull Shapes' (Mancuso 2006) and 'Automatic Surface Modeling of a Ship Hull' (Arribas et al. 2006, 584-594) studies develop ideas on how to create yacht forms using computer-aided methods. "Ship Design Computer Programs - An Interpolative Technique" refers to use of these computer programs has allowed the designer to develop the most accurate design solutions in stage preliminary, initial and contract design (Kenneth et al, 1986). Many geometric modeling programs are used in the discipline of naval engineering. Rhinoceros software is also widely used in this area. However, most people only model the superstructure or visualize blocks modeled in a different program, failing to use the software to its full potential. Besides, this software was not developed for the particular use of naval engineers. Software such as FastShip, AutoShip, MaxSurf, MultiSurf, BEAN - The Virtual Shipyard, DELFTship, Pilot3D, ShipConstructor, MasterShip and MAAT 2000 were specifically developed for naval engineers. The goal is to use not only the software created for naval engineers but also Rhinoceros, which facilitates parametric design. To this end, the proposed model was integrated into Rhinoceros.

As a start, importing the yacht's hull into the model. The hull is imported into the model created by a naval engineer based on the desired dimensions and specifications.

\section{Superstructure}

Based on an examination of sailing yacht typology, it has been determined that the examples that reflect this typology the best are between 8 and 18 meters in length. The most important sailing yacht manufacturers in the industry are Bavaria, Beneteau, Dufour, Jeanneau and Hanse. In order to analyze the sailing yacht typology and interior layout, the sailing yachts of these shipbuilders were examined to make a broad deduction. An analysis of the sailing yachts of top manufacturers within the range of 8 to 18 meters in length has revealed that superstructures are similar in typology. A terminology that includes terms such as cockpit, stern, fore, bulwark, mast, porthole and hatch has been employed to describe sailing yacht superstructure. These terms are presented and briefly described in Figure 1. Well deck is the sitting area on the stern or amidships. Hatch is the cover that opens from the cabin ceiling. Portholes are the windows on the board or sides of the cabin. Stern and fore are the rear and front parts of the yacht, respectively. The mast is a rigging element of a certain height, generally made from aluminum alloy, positioned vertically on the keel and is used to raise the sails.

The variables needed to create the superstructure are defined in Table 1.

The variables defined in Table 1 are shown on a sample sailing yacht model in Figure 2.

Analysis of the seating units has shown that straight seating units as well as U- and süreci doğru bir şekilde tamamlanmış olacaktır.

Keywords: Sailing Yacht, Parametric Design, Yacht Design, Computer Aided Design

Anahtar Kelimeler: Yelkenli Yatlar, Parametrik Tasarım, Yat Tasarımı, Bilgisayar Destekli Tasarım

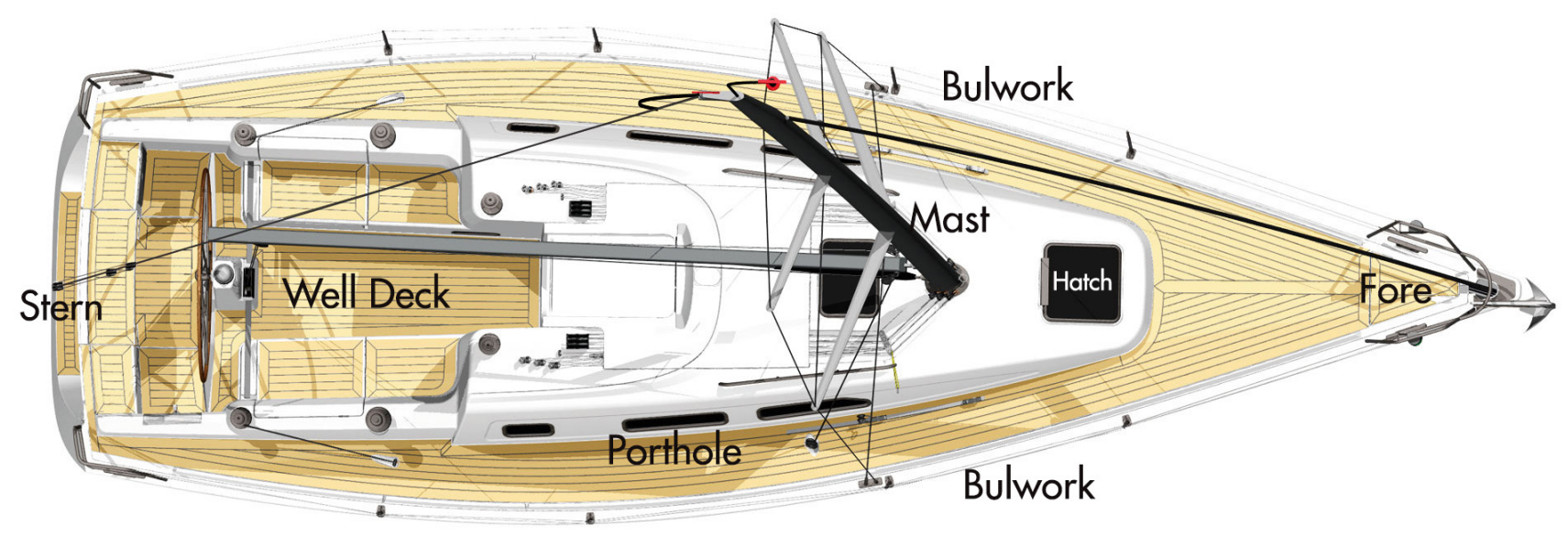


Table: I

Parameters to create superstructure (Data Suggested by Author).

Figure: 2

Displaying the Terms on the Model (Data suggested by Author).

\begin{tabular}{|l|l|l|l|}
\hline Abbreviation & Explanation & Abbreviation & Explanation \\
\hline Ss & Superstructure start from yacht beak & & \\
\hline Dw & Deck walking width & & \\
\hline Sf & Superstructure finish from yacht stern & & \\
\hline $\mathrm{Cl}$ & Cocpit length & & \\
\hline $\mathrm{Cw}$ & Cocpit width & & \\
\hline Sp-a & Sitting area port side width & Ss- a & Sitting area starboard side width \\
\hline Sp-b & Sitting area port side & Ss- b & Sitting area starboard side \\
\hline Sp-c & Sitting area port side & Ss- c & Sitting area starboard side \\
\hline Sp-d & Sitting area port side & Ss- d & Sitting area starboard side \\
\hline Sh & Sitting area height & Shs & Superstructure start point height \\
\hline Sb & Sitting area back height & Shm & Superstructure midpoint height \\
\hline St & Sitting area back thickness & She & Superstructure end point height \\
\hline $\mathrm{Cd}$ & Cocpit area and deck depth difference & & \\
\hline Ldd & $\begin{array}{l}\text { Lower deck and cocpit area deck depth } \\
\text { difference }\end{array}$ & & \\
\hline $\mathrm{Mc}$ & Mast center point from yacht beak & & \\
\hline $\mathrm{Mh}$ & Mast height & & \\
\hline $\mathrm{Mr}$ & Mast Radius & & \\
\hline $\mathrm{Ss}$ & Superstructure start from yacht beak & & \\
\hline $\mathrm{Dw}$ & Deck walking width & & \\
\hline & & & \\
\hline
\end{tabular}

L-shaped sitting units are used in some examples. Therefore, parameters shown in Figure 3 are used in the arrangement of the port- and starboard-side sitting units.

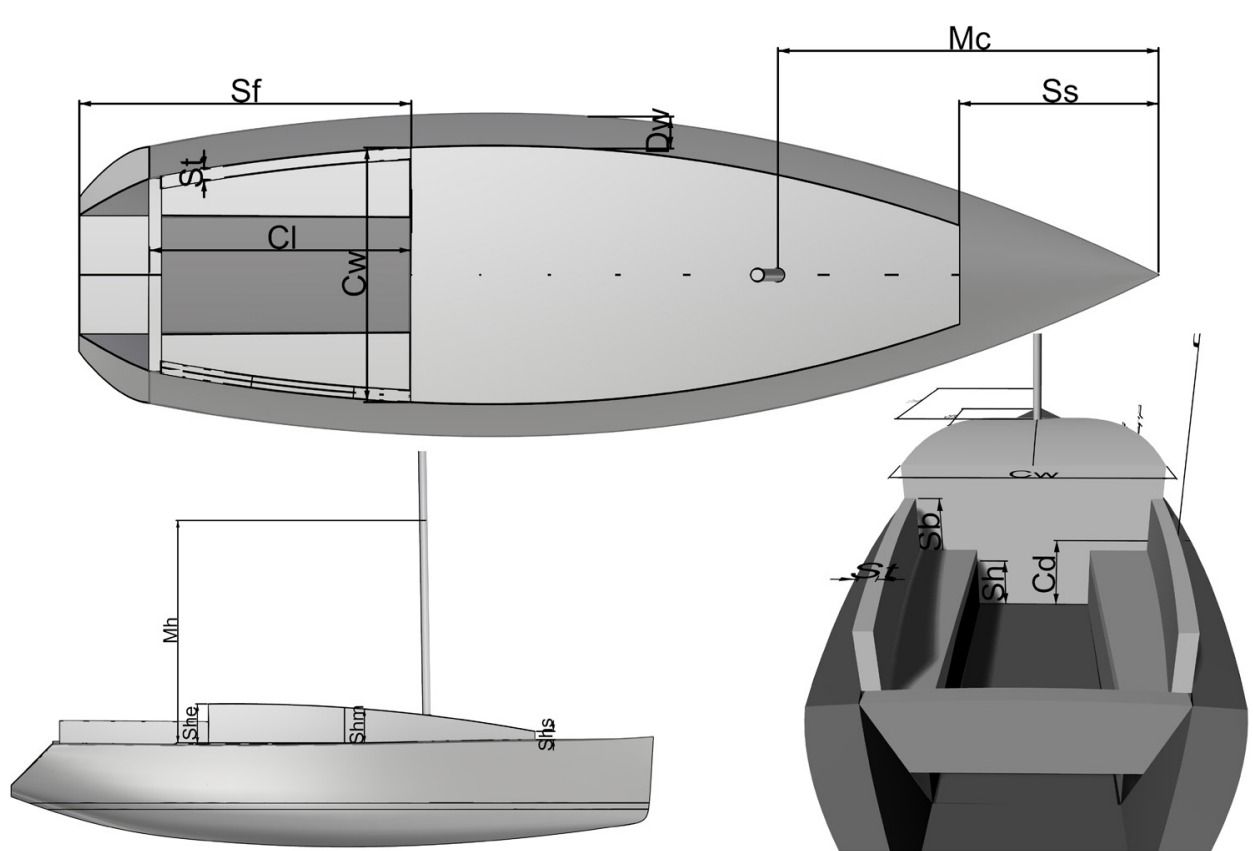




\section{Sltting area port side}
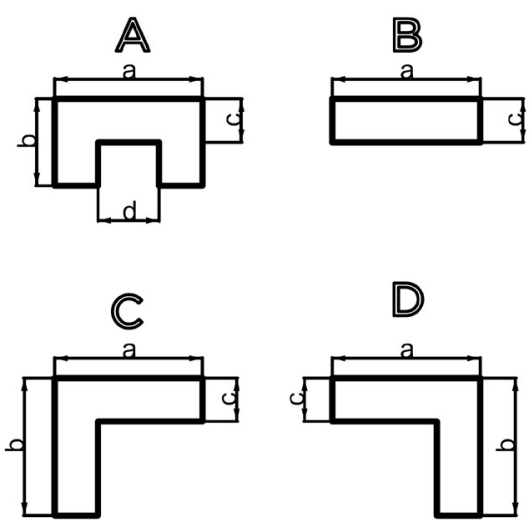

deck, called the open deck walking area, and an interior floor that forms the base of the well deck. Knowing the variable of the deck floor depth difference between the well deck and the floor is enough to form the interior floor. Knowing the depth difference with the well deck and lower deck is enough to form the lower deck floor. The floors are designed by creating a flat surface and sectioning it with the superstructure, and with the hull on the lower deck. The variables defined in Figure 4 are shown on a sailing yacht model example.

It is observed that interiors of sailing yachts are generally not comfortable to live in. As sailing yachts usually have flush decks, their cabins are cramped, small wet areas
Sitting area starboard side
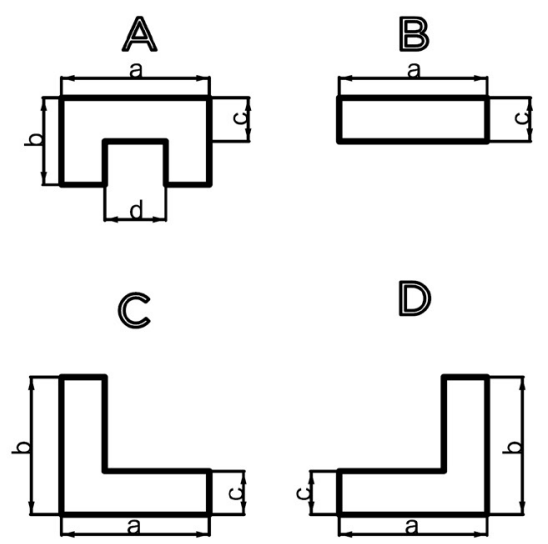

with depressed ceilings. In some cases, it is observed that superstructures go higher as yachts grow; however, this is objectionable and goes against the typology. Although sailing yachts claim to provide the luxuries of a motor yacht in some cases through the harmony of interior and exterior design, the important point is to shape the typology according to the purpose of yachting. Priority in the creation of visual balance in the image of a sailing yacht is given to the harmony between the sail and the hull (Göksel, 2006, 95-98).

The living space on sailing yachts is a shared space with functions such as eating, sitting and resting, and is connected to kitchen and navigation spaces. This section is positioned amidships, which is the
Figure: 3

Sitting Area Parameters (Data Suggested by Author).

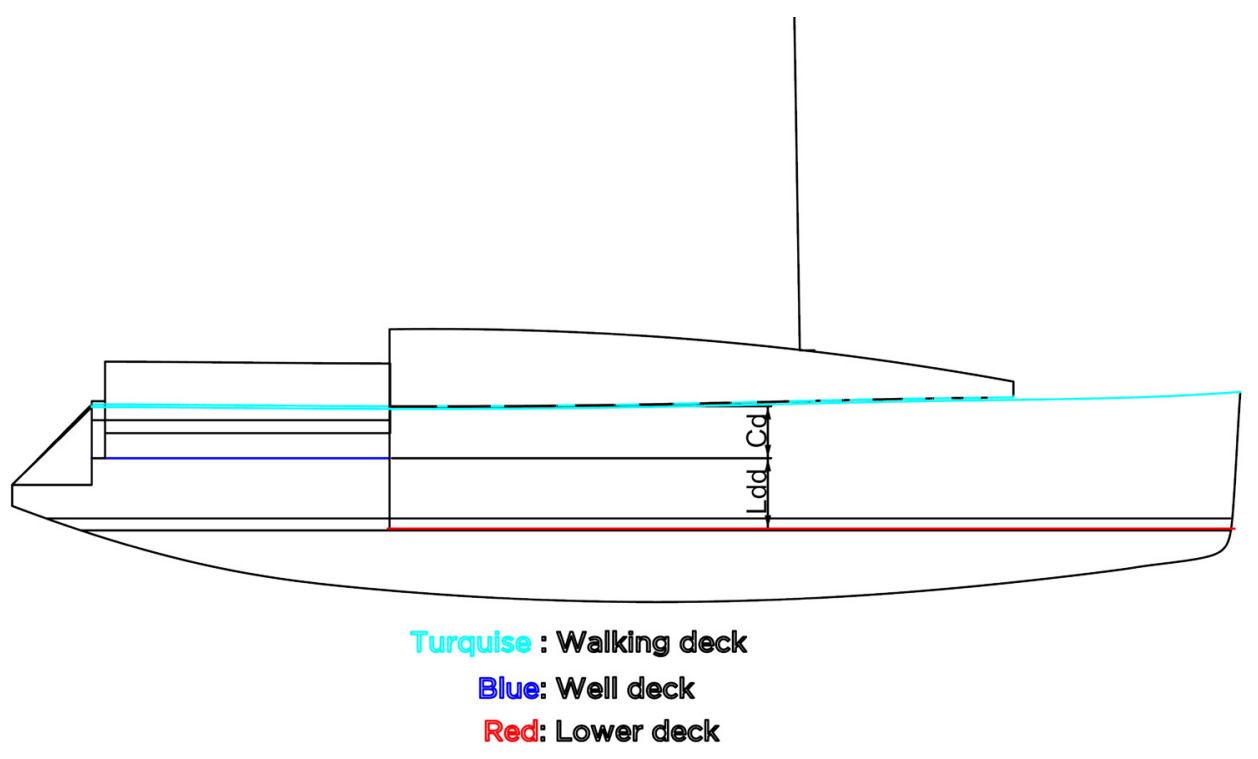

Figure: 4

Deck Terms on the Sailing Yacht Model (Data suggested by Author). 

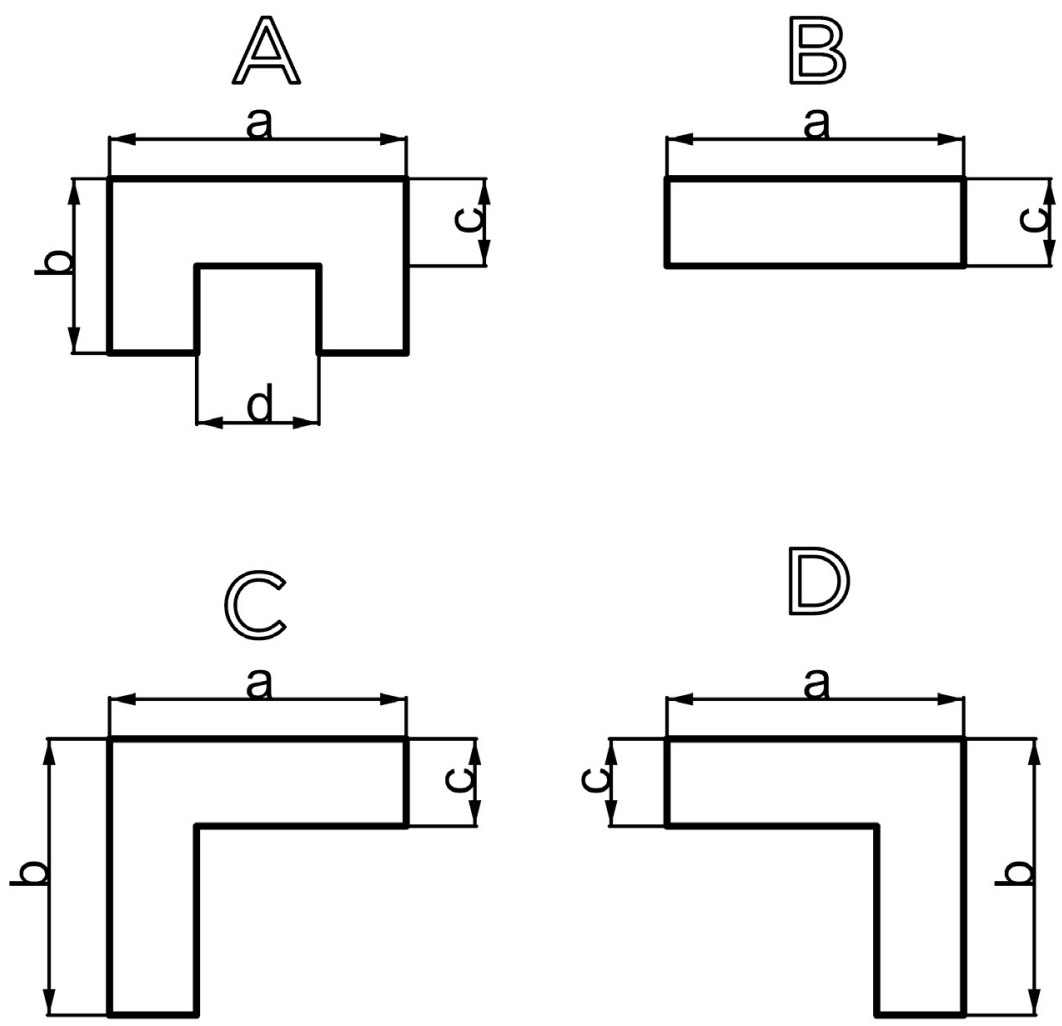

Figure: 5

Parameters According to Seating Area Alternatives (Data Suggested by Author).

Figure: 6

Parameters According to Seating Area Alternatives (Data Suggested by Author).
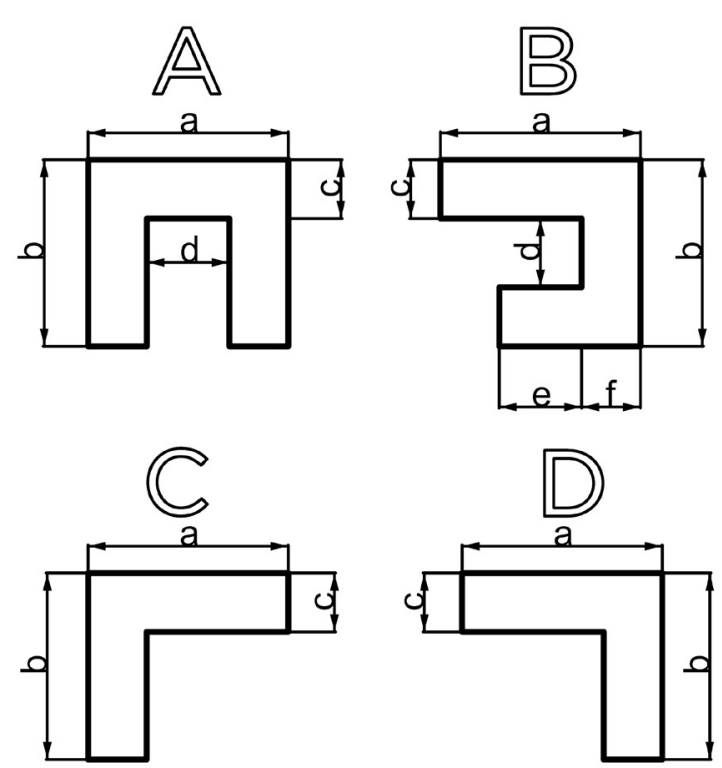

arrangement makes it easier to enter and exit. However, the available area is not fully utilized. The seating elements are preferred to be about 2 meters in length, as they are also used for sleeping. If the user chooses a length under two meters, the system should give a warning. Parametric variables depend on the selected seating type. The system recommends alternative A when U-shaped seating is selected, alternative $B$ when straight seating is selected, and alternatives C and D L-shaped seating is selected. Required variables according to the selected alternative are shown in Figure 5.

\section{Staircase}

The staircase that connects interiors and exteriors is built flat in some designs, and concave shaped in others. The difference in depth between the upper deck floor and the lower deck floor is known. The width and number of stairs and the footstep between the stairs is enough to create the staircase. The user should be asked if they want a flat design or a concave one.

\section{The Kitchen}

While the kitchen used to be placed any given space on the lower deck in the past, it is now mostly located near the entrance staircase because this section is minimally affected by the pitching (Larsson and Rolf, 2006). U-shaped, L-shaped and straight counter builds are found in kitchen plans. Parametric variables depend on the selected kitchen type.

Alternatives A and B are recommended when a U-type kitchen is selected, alternatives $\mathrm{C}$ and $\mathrm{D}$ are recommended when an L-type kitchen is selected, and alternative $\mathrm{E}$ is recommended when a flat counter is selected. The desired variables according to the selected alternate are shown in Figure 6. The system recommends alternative $\mathrm{A}$ and $\mathrm{B}$ when a U-shaped kitchen is selected, alternatives $\mathrm{C}$ and $\mathrm{D}$ when an L-shaped kitchen is selected, and alternative E when a straight kitchen is selected. Required variables according to the selected alternative are shown in Figure 6. 


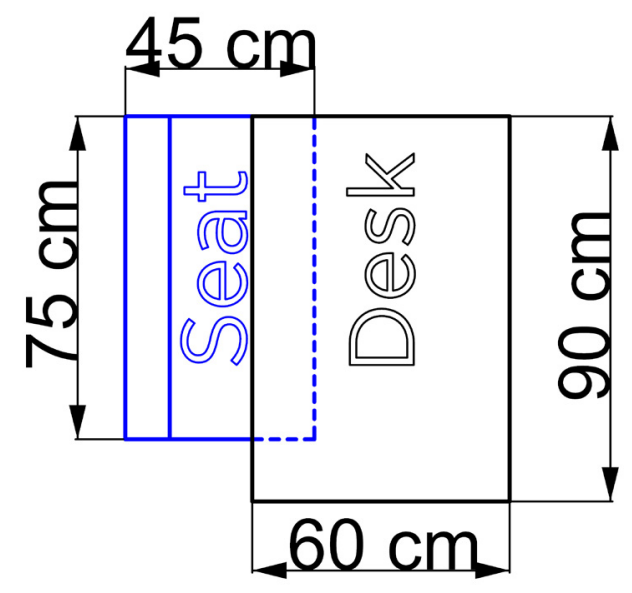

The Navigation Space

The main function of this space is to work on a map and the space includes a map desk and a seating element for this purpose. Although there are electronic map systems, this area is still needed. According to Hammick and McLaren, an area of $84 \times 59.5 \mathrm{~cm}$ will suffice to fold and use standard British maps or European maps (Tokol, 2013, 119-120). The user will be prompted to choose the location of the navigation space and a standard table and seating element will be automatically inserted, as shown in Figure 7.

\section{Master and Guest Cabins}

The number and dimensions of cabins vary according to the size of the vessel, the purpose of use and the number of crewmembers. The basic function is sleeping and resting. The types of beds used in yachts are presented in Figure 8. These beds are
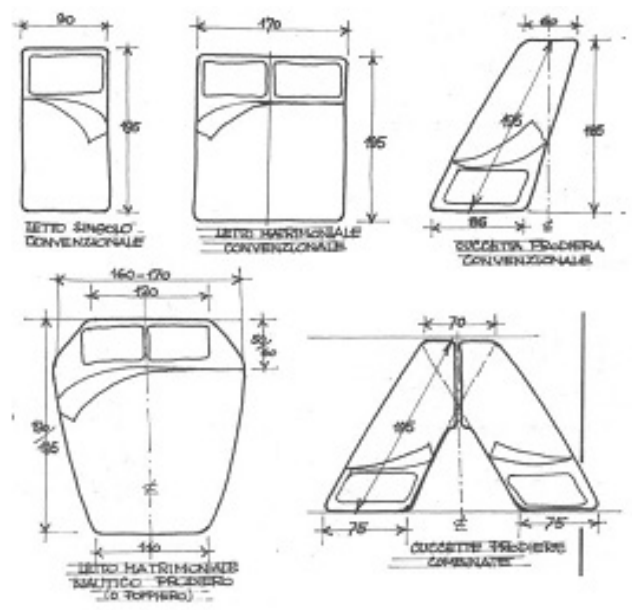

also used in sailing yachts. The user is first asked which areas are to be used for cabins and their dimensions. Secondly, the user is asked which bed type they want to add. Bed sizes are automatically added (Figure 8). Their position can be inverted in the X-Y axis and/or their angle can be changed.

\section{WC-Bathroom Space}

Analysis of the examples according to the yacht length has shown that there are one or two WCs available for use. The user is first asked how many WCs are to be added and, then, which WC type they want to add (Figure 9). WCs used in yachts come in five types (Özgel Felek, 2017, 71-76). In the proposed model, WC examples are limited to five types. These alternatives, which have distinctive features, are wall-mounted electric toilets, large and small electric toilets, and large and small marine type toilets. Vetus brand WCL2 model was created for the wall mounted electric toilet. The Vetus WCS2 model has been created for large and small sized electric toilets. RASKE RM69 model was created for marine type large and small size toilets. The user should be asked about these alternative types, and the type should be automatically added with the option to invert the $\mathrm{X}-\mathrm{Y}$ axis and rotate the angle. The countertop and shower area can be manually added to the project later.

\section{The Definition and Scope of Model}

The study dwells upon superstructure and interior space layouts. In this study, the superstructure is modeled in $3 \mathrm{D}$ and the in-

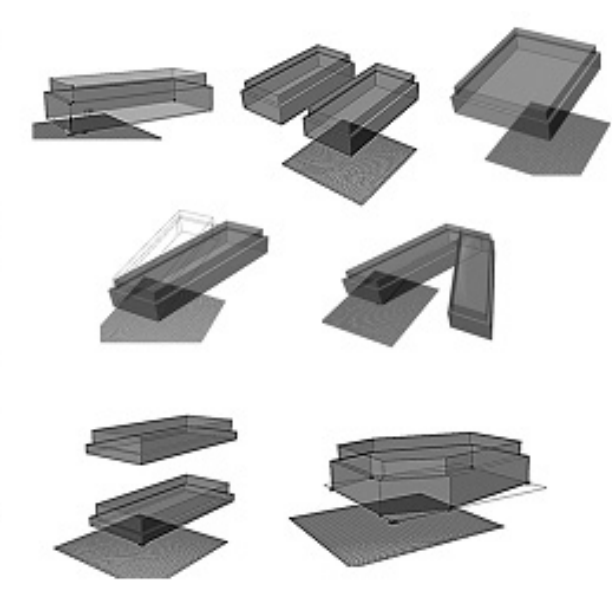

Figure: 7

Navigation Space Automatic Model (Data Suggested by Author). 


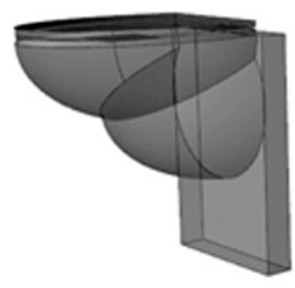

Figure: 9

WC Types (Özgel Felek, 2017, 71-76).
Figure: 10

Superstructure and Walking Area Borders Express in Colors (Data Suggested by Author).

Figure: II

Superstructure Modelling (Data Suggested by Author).
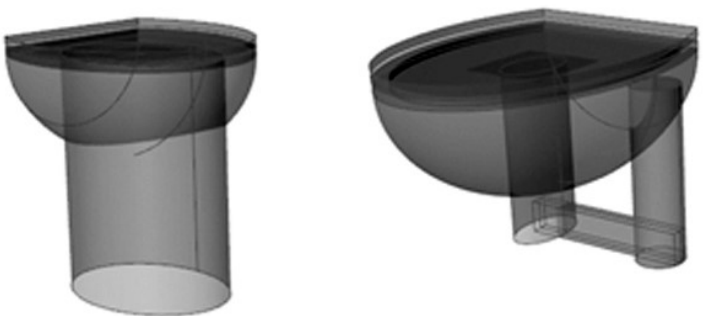

terior model is initially examined through the plans of the generated models. In the study, alternative layouts of seating, kitchen, resting and $\mathrm{WC}$ areas, which are among the spatial elements of the yacht, were produced on the lower deck. The method used to develop these proposals was Grasshopper, a free plugin of Rhinoceros that allows parametric modeling on the upper deck, and an algorithm was generated for the lower deck and imported to the digital platform with $\mathrm{C \#}$. This program offers designers alternatives to the plan schemes in the initial design phase.

\section{Rules and Boundaries for Superstructure}

The first step to creating a model is to determine the criteria and present the information that may serve as a foundation. Hull design is a field of interest and knowledge of naval engineers. In the first stage, a three-dimensional model of the hull form is imported into the model. This hull introduced to the program and the following stages are built upon it (Figure 10).

- Border line of the hull/the boundaries (red)

- Superstructure start from the fore (green)

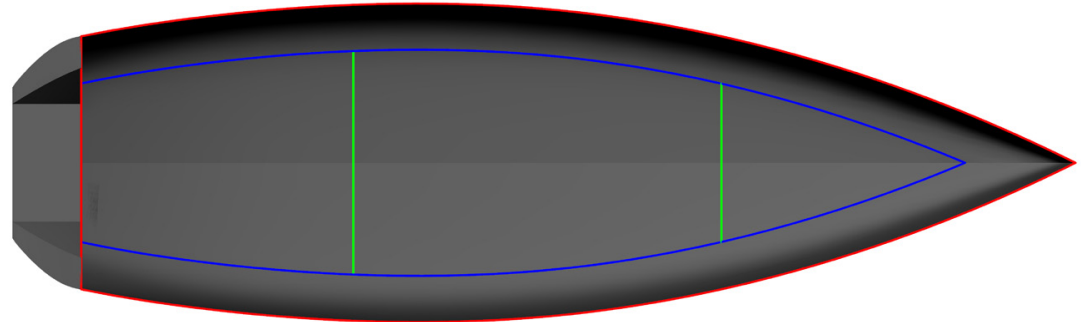

- Superstructure end from the stern (cyan)

- Walking deck width (blue) are identified, and borders of the superstructure are revealed.

The superstructure is modeled according to the variables of the start, middle and backrest height. The start, middle and end height lines (magenta colored) are drawn, and the curve of these lines (gold colored) is the middle section of the upper structure. The superstructure is modeled by extending this curve to both sides and sectioning it with border curves of the superstructure and extruding surfaces in between (Figure 11). In order to form the well deck, firstly the variable of depth difference with the deck should be asked to create the floor. This is defined as the remaining surface after the flat surface is sectioned with the hull and the superstructure. The well deck is formed according to the variables of well deck length, width, sitting width, and sitting backrest height. The superstructure is revealed in 3D after these phases (Figure 12).

\section{Rules and boundaries for Lower Deck}

The floor must first be created in order to form the lower deck boundary. The lower deck plan is revealed when the surface is created by asking for the difference in depth between the well deck and the lower deck floor is sectioned with the hull. Due to the inclined walls of the yacht geometry, working in 2D (two dimension) does not yield accurate results. This attempt can be misleading. Although general layout alternatives are presented to the user in the first stage, a sketch of the alternative selected by the user is immediately previewed in 3D (three dimension). Thus, the result of the selections is also seen in $3 \mathrm{D}$.

For the lower deck layout, the fore and stern border walls are placed first and boundaries are determined. Vertical walls start from the stern. Vertical walls are
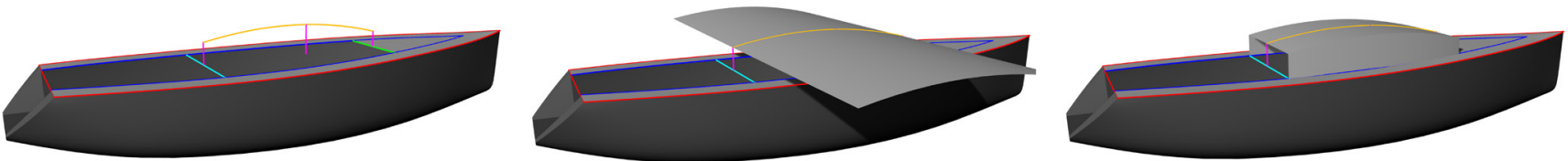


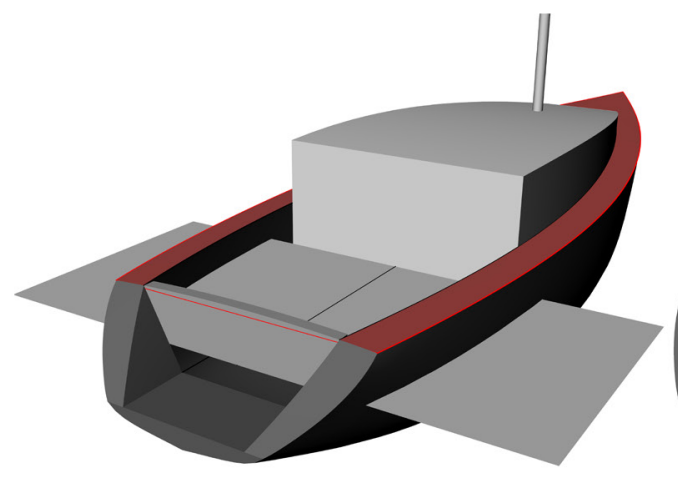

called wall vertical (Wv), and horizontal walls are wall horizontal (Wh). The first wall from the stern is called the distance from the stern, the second wall is the distance from the first wall, and the third wall is the distance from the second wall, and so on. A maximum of six vertical walls can be added. Based on a review of

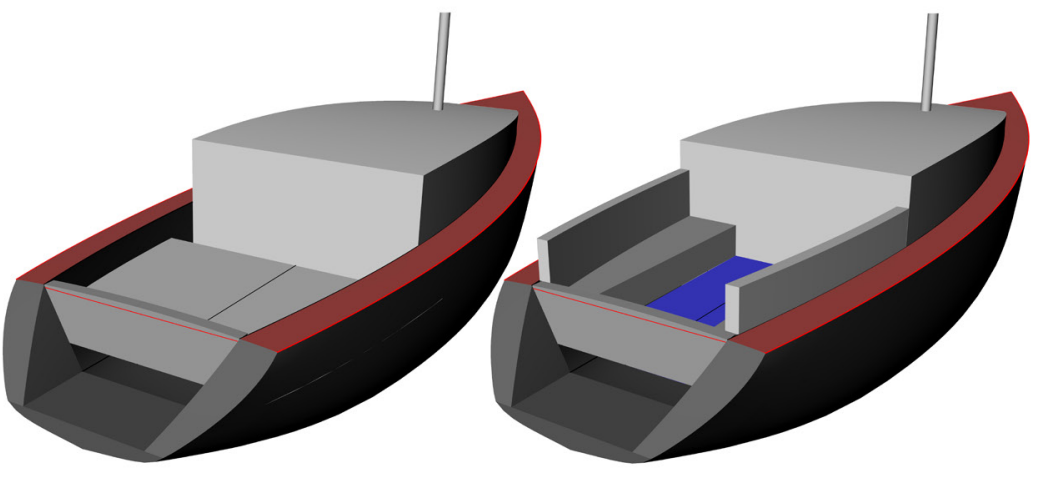

all plan examples, it is enough to divide three horizontal parts. Horizontal walls are Figure: 12 Well Deck Formation (Data Suggested by Author). constructed as horizontal 1 and horizontal 2 according to the distance from the centerline (Figure 13). Each new vertical wall part is separated from the intersection with the horizontal walls so that they can be angled. While $\mathrm{W} 1 \mathrm{v}$ is the entire vertical wall, the
Figure: 13

Horizontal and Vertical Walls Formation (Data Suggested by Author).
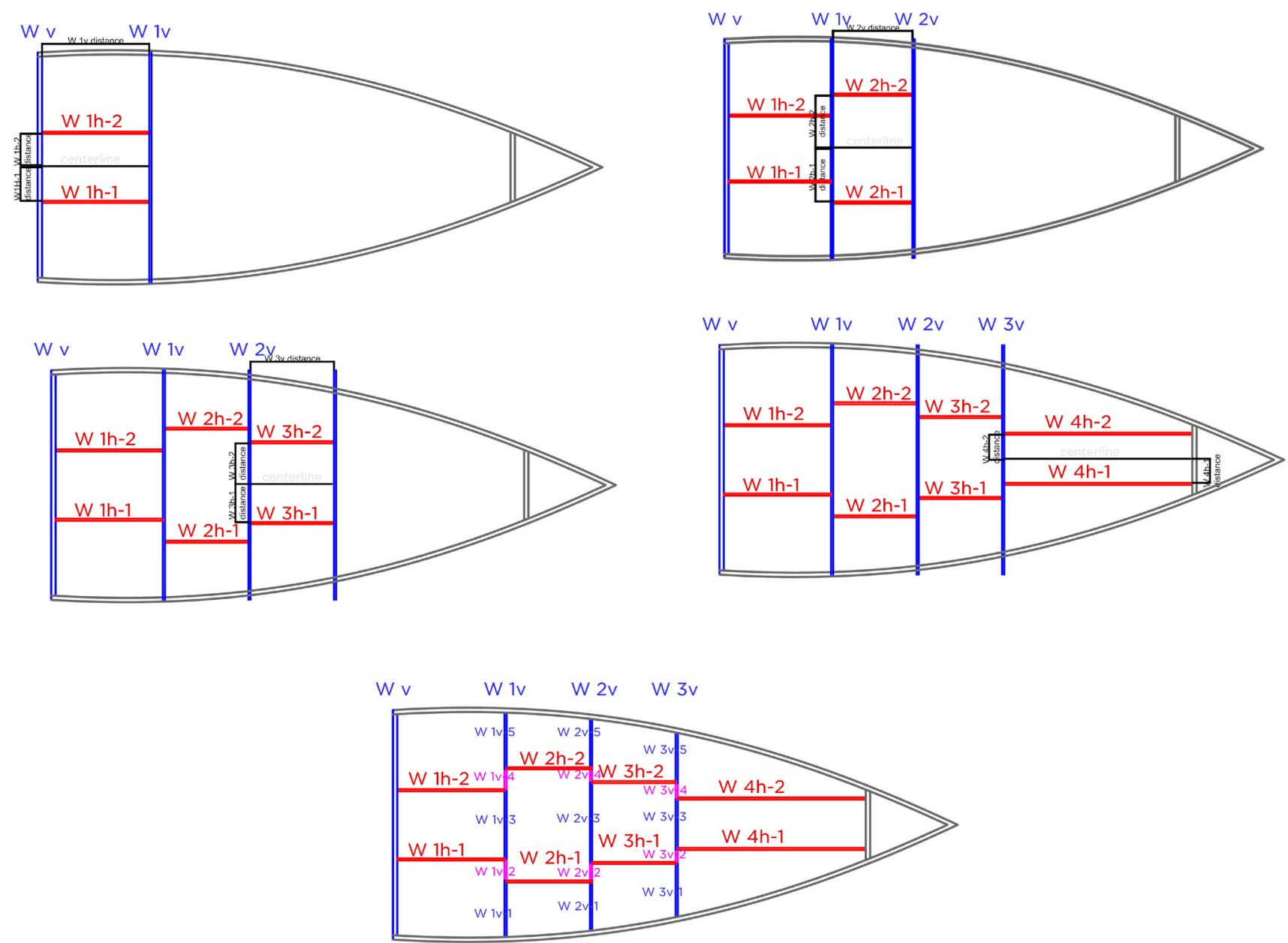

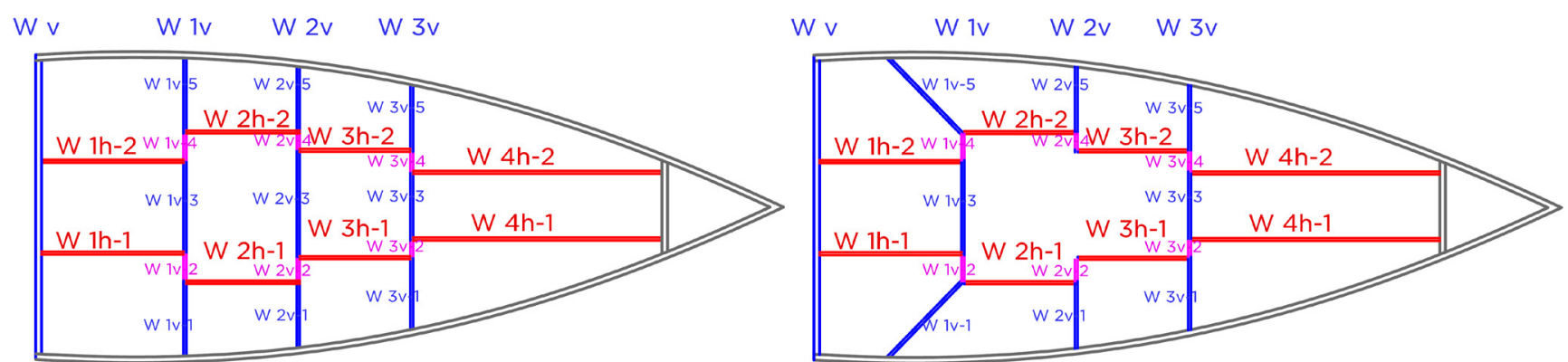

Figure: 14

Give Angle to Vertical Walls (Data Suggested by Author).
Figure: is

Matching Room and Types (Data Suggested by Author).

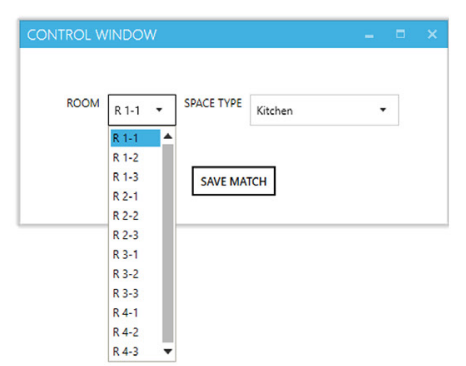

parts can be separated as $\mathrm{W} 1 \mathrm{v}-1, \mathrm{~W} 1 \mathrm{v}-2$, W $1 \mathrm{v}-3, \mathrm{~W} 1 \mathrm{v}-4$ and $\mathrm{W} 1 \mathrm{v}-5$ and can be angled or hidden like they were in $\mathrm{W} 2 \mathrm{v} 3$, as shown in Figure 14. Any desired plan can be created this way.

- Fields formed by wall formation are named and it is requested that these areas be matched as kitchen/sitting/ cabin/WC/navigation area (Figure 15).

- Variables for each field are also asked after matching the rooms.

- Figure 16 shows the interface of the desired variables when the kitchen is selected.

- Figure 17 shows the interface of the desired variables when the seating area is selected.

- Figure 18 shows the interface of the desired variables when cabinet is selected. In addition, for the cabinet that the cabin needs, the width and depth of the cabinet are needed.
Height is automatically modeled from the ground to the ceiling.

- Figure 19 shows which toilet type selection interface is selected when $\mathrm{WC}$ is selected.

- If the user first sees the alternatives on 2D grid system and approves it, then this information is processed with Grasshopper and rendered into 3D.

\section{Yacht Formation Example with the Proposed Model}

The Beneteau Sense 51 model was chosen to be built with the proposed model.

\section{Superstructure and Deck Formation}

The superstructure variable information of the Sense 51 yacht and the interface in which these variables are entered are shown in Figure 20.

The resulting superstructure and 3D model of the well deck are given comparatively in Figure 21.

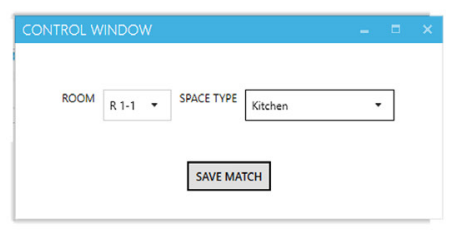

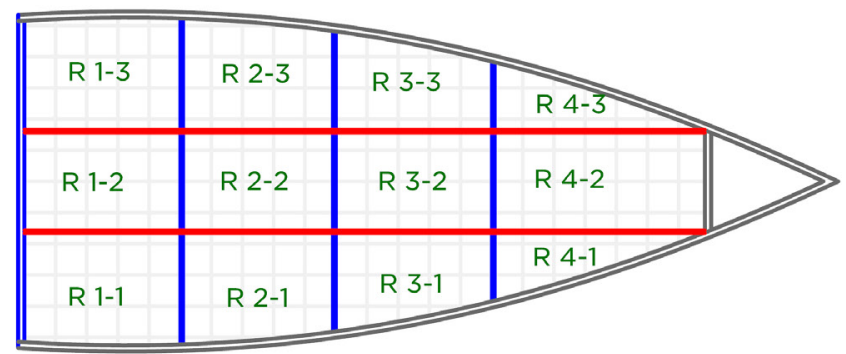

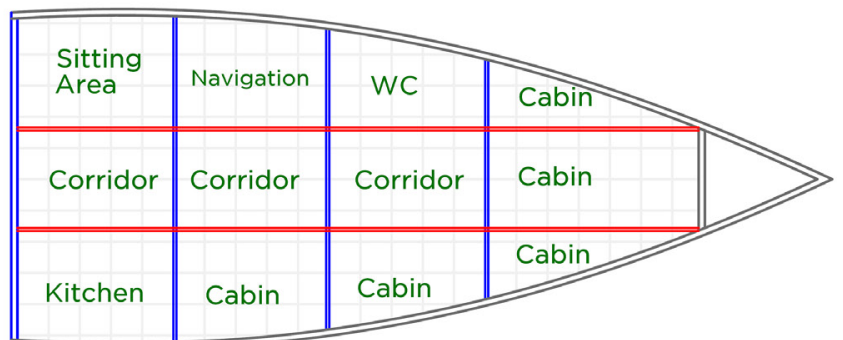




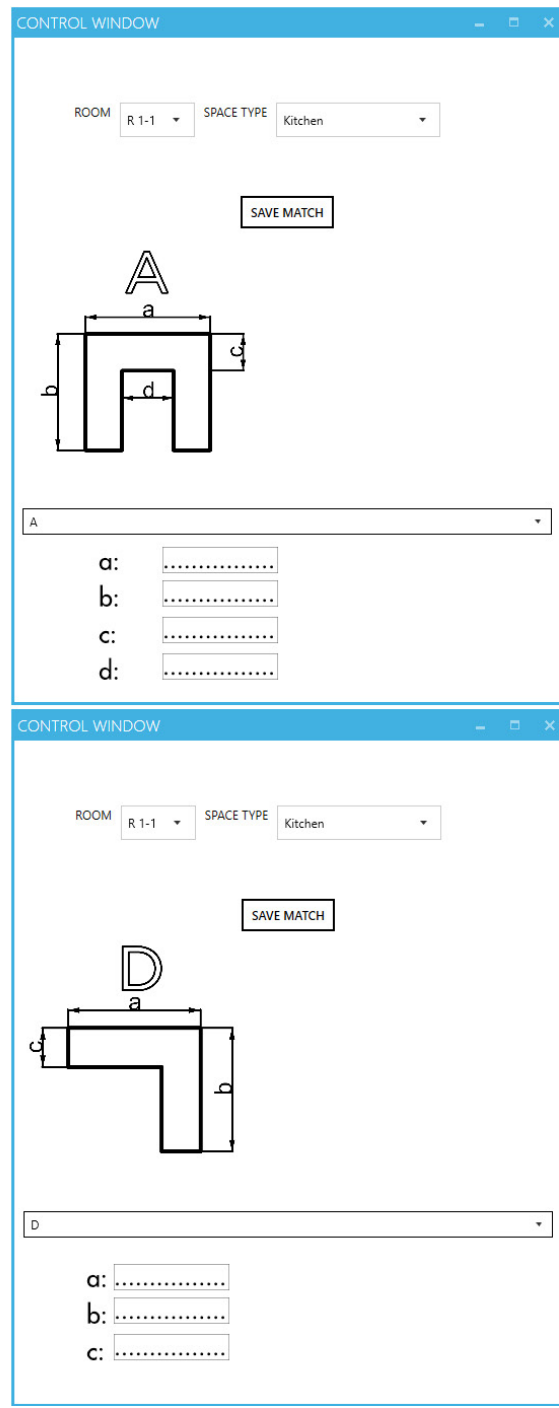

Creating the General Interior Layout

The boundaries of the living area can be formed to place the lower deck floor, head and stern border walls. It is necessary to construct walls to form the lower deck layout. Using the quantitative information obtained from the layout plan of the selected yachts, an attempt was made to create the model based on the parameters (Figure 22). The number and presentation of the walls were based on the yacht example, and the spaces were named on the volumes, as shown in Figure 23. The wall thickness was 10 centimeters.

After matching the volumes:

- Alternative placement for kitchen

- Alternative placement for the living area
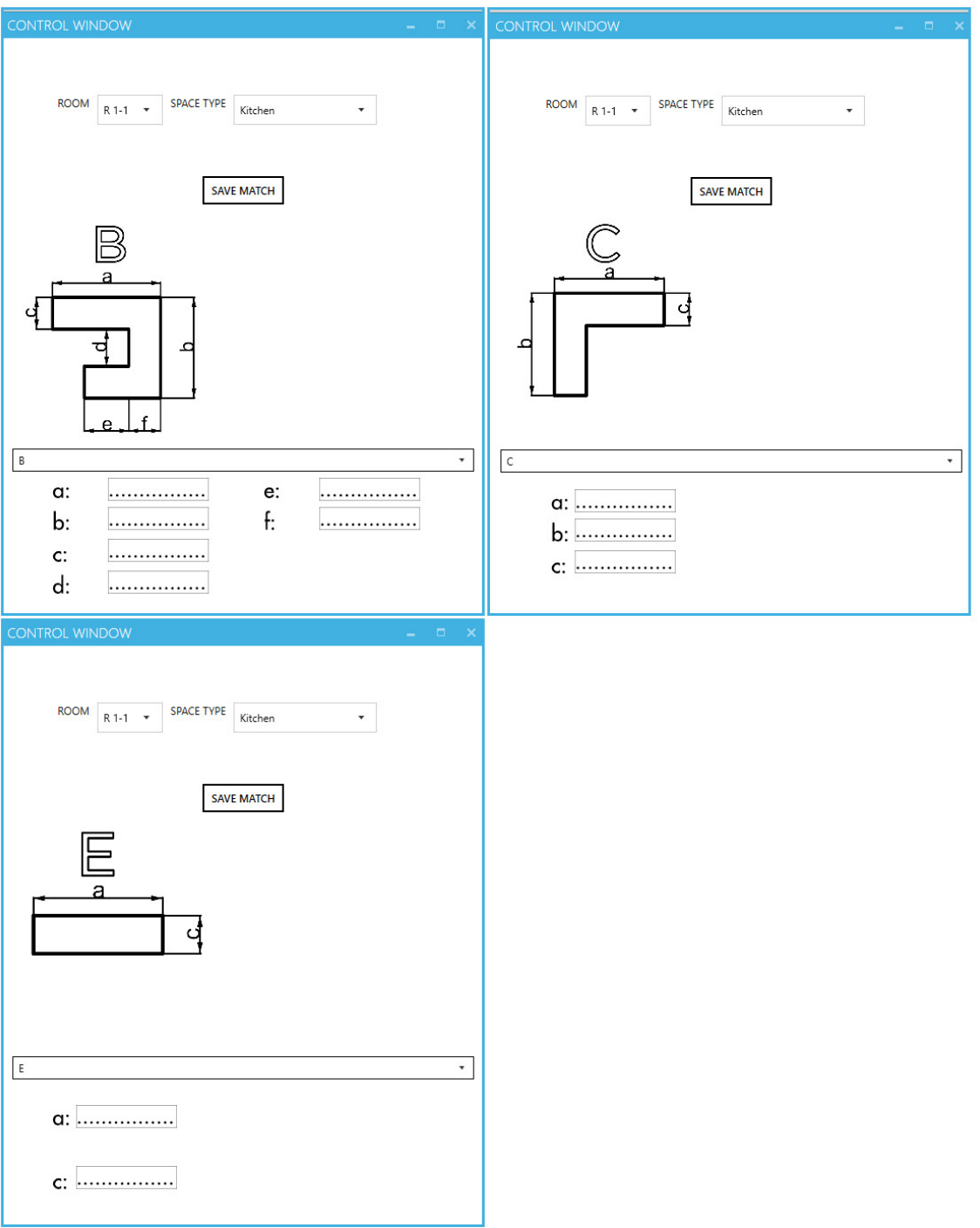

- Selection of navigation area layout

- Selection of number and placement

Figure: 16

Kitchen Parameters interface (Data suggested by Author). of sleeping areas

- Selection of WC number and location

Figure 24 shows a comparison of the resulting alternative plan with the original yacht. According to the comparison, the hull and inclined walls were ignored in the $2 \mathrm{D}$ layout. The resulting layout will be more correct because when the 3D model is automatically generated, all these surfaces will be sectioned with the hull.

The general 2D layout plan is transferred to the 3D model in stages. In the first stage, the walls are extruded and created in $3 \mathrm{D}$. When the sitting/eating area is placed, the model automatically gener- 

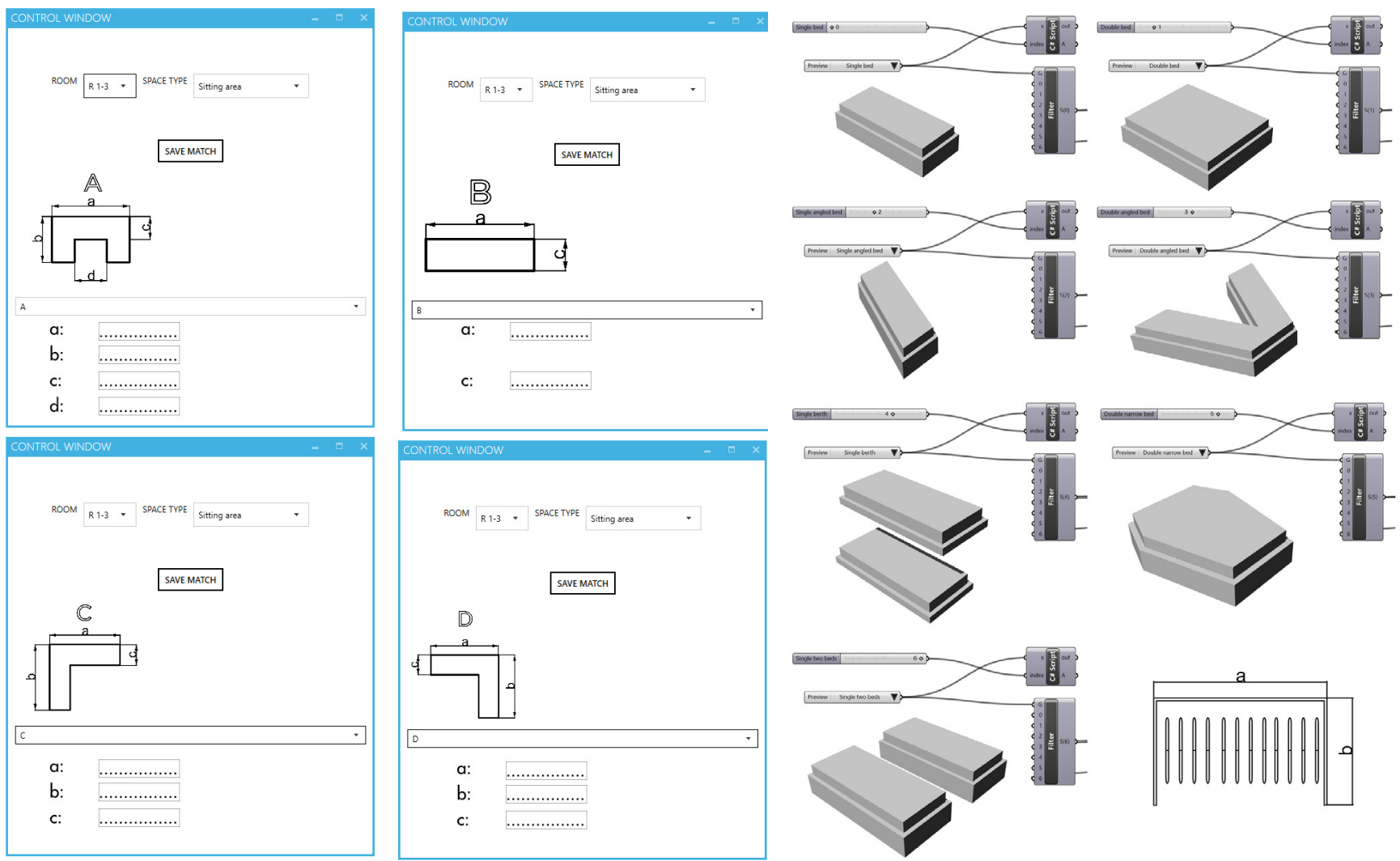

Figure: 17

Sitting Area Parameters Interface (Data Suggested by Author).

Figure: 18

Cabin Beds Alternatives Interface and Closet Parameters (Data Suggested by Author).

\section{Figure: 19}

WC Alternatives Interface (Data Suggested by Author).
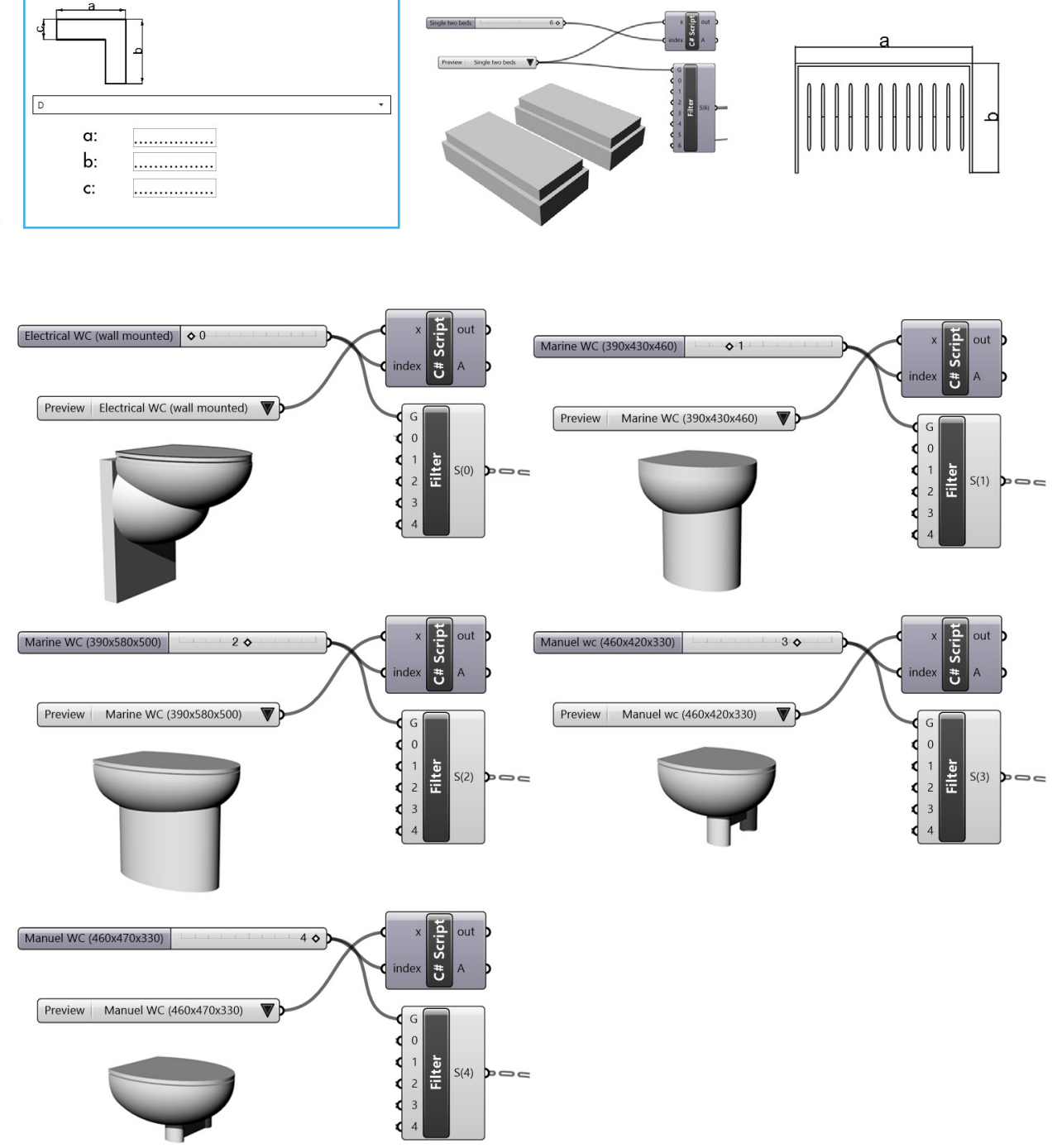


\begin{tabular}{|c|c|c|c|c|c|}
\hline SUPER & STRUCTL & & & & $=\square x$ \\
\hline Ss & $380 \mathrm{~cm}$ & $\begin{array}{l}\text { SUPERSTRUCTURE START } \\
\text { FROM YACHT BEAK }\end{array}$ & Sh & $110 \mathrm{~cm}$ & SITTING AREA HEIGHT \\
\hline Dw & $54 \mathrm{~cm}$ & DECK WALKING WIDTH & $\mathrm{Sb}$ & $40 \mathrm{~cm}$ & SITTING AREA BACK HEIGHT \\
\hline Sf & $440 \mathrm{~cm}$ & $\begin{array}{l}\text { SUPERSTRUCTURE FINISH } \\
\text { FROM YACHT STERN }\end{array}$ & St & $10 \mathrm{~cm}$ & SITTING AREA BACK THICKNESS \\
\hline $\mathrm{Cl}$ & $340 \mathrm{~cm}$ & COCPIT LENGTH & Shs & $10 \mathrm{~cm}$ & $\begin{array}{l}\text { SUPERSTRUCTURE } \\
\text { START POINT HEIGHT }\end{array}$ \\
\hline $\mathrm{Cw}$ & $330 \mathrm{~cm}$ & COCPIT WIDTH & Shm & $45 \mathrm{~cm}$ & $\begin{array}{l}\text { SUPERSTRUCTURE } \\
\text { MIDPOINT HEIGHT }\end{array}$ \\
\hline Sp-a & $241 \mathrm{~cm}$ & $\begin{array}{l}\text { SITTING AREA } \\
\text { PORT SIDE WIDTH }\end{array}$ & She & $50 \mathrm{~cm}$ & $\begin{array}{l}\text { SUPERSTRUCTURE } \\
\text { END POINT HEIGHT }\end{array}$ \\
\hline Sp-b & $\cdot$ & $\begin{array}{l}\text { SITTING AREA } \\
\text { PORT SIDE }\end{array}$ & $\mathrm{Cd}$ & $80 \mathrm{~cm}$ & $\begin{array}{l}\text { COCPIT AREA AND } \\
\text { DECK DEPTH DIFFERENCE }\end{array}$ \\
\hline Sp-c & $50 \mathrm{~cm}$ & $\begin{array}{l}\text { SITTING AREA } \\
\text { PORT SIDE }\end{array}$ & Ldd & $60 \mathrm{~cm}$ & $\begin{array}{l}\text { LOWER DECK AND COCPIT } \\
\text { AREA DECK DEPTH DIFFERENCE }\end{array}$ \\
\hline Sp-d & $\cdot$ & $\begin{array}{l}\text { SITTINC AREA } \\
\text { PORT SIDE }\end{array}$ & Mc & $650 \mathrm{~cm}$ & $\begin{array}{l}\text { MAST CENTER POINT } \\
\text { FROM YACHT BEAK }\end{array}$ \\
\hline Ss-a & $241 \mathrm{~cm}$ & $\begin{array}{l}\text { SITTING AREA } \\
\text { STARBIOARD SIDE WIDTH }\end{array}$ & $\mathrm{Mh}$ & $2200 \mathrm{~cm}$ & MAST HEIGHT \\
\hline Ss-b & $100 \mathrm{~cm}$ & $\begin{array}{l}\text { SITTING AREA } \\
\text { STARBIOARD SIDE }\end{array}$ & $\mathrm{Mr}$ & $20 \mathrm{~cm}$ & MAST HEIGHT \\
\hline Ss-c & $50 \mathrm{~cm}$ & $\begin{array}{l}\text { SITTING AREA } \\
\text { STARBIOARD SIDE }\end{array}$ & & & \\
\hline Ss-d & $122 \mathrm{~cm}$ & $\begin{array}{l}\text { SITTING AREA } \\
\text { STARBIOARD SIDE }\end{array}$ & & & \\
\hline
\end{tabular}

Save and Apply Parameters

ates the backrest height and sitting height of the area defined as the sitting area. Similarly, table height is automatically generated. When the kitchen is placed, the height of the counter is automatically generated by the model. When the cabin is placed, the height of the bed is auto- matically set. WCs are placed by adding auto 3D models. A rough model appears when all the layouts are generated. Using the properties of the program, the X, Y, Z parameters can be changed or angled, or undesired blocks can be deleted, and new ones can be added manually. Figure 25
Figure: 20

Superstructure Parameters Interface (Data suggested by Author).
Figure: 21

Main Yacht and The Yacht by Model superstructure Comparison (Data Suggested by Author).

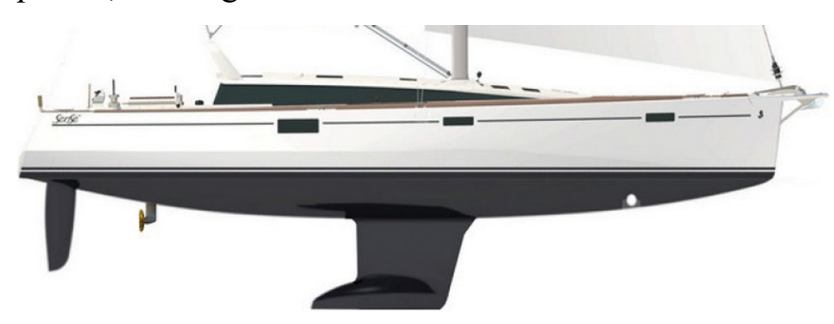

MAIN YACHT
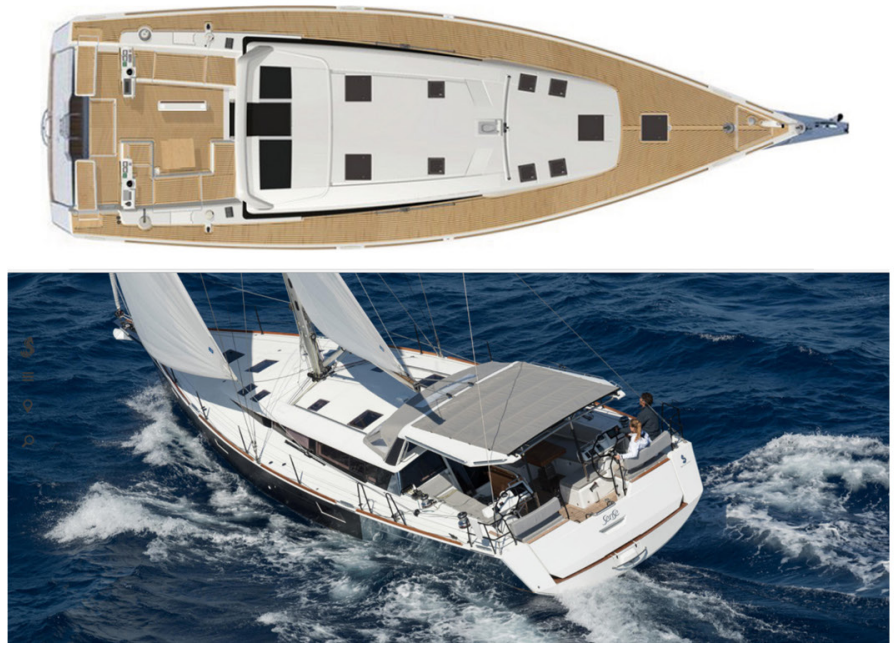

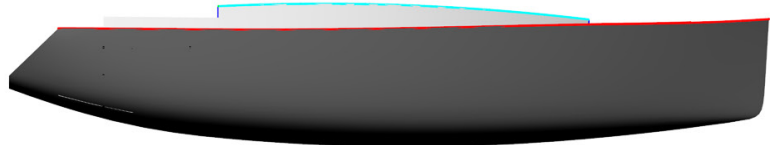

YACHT BY MODEL
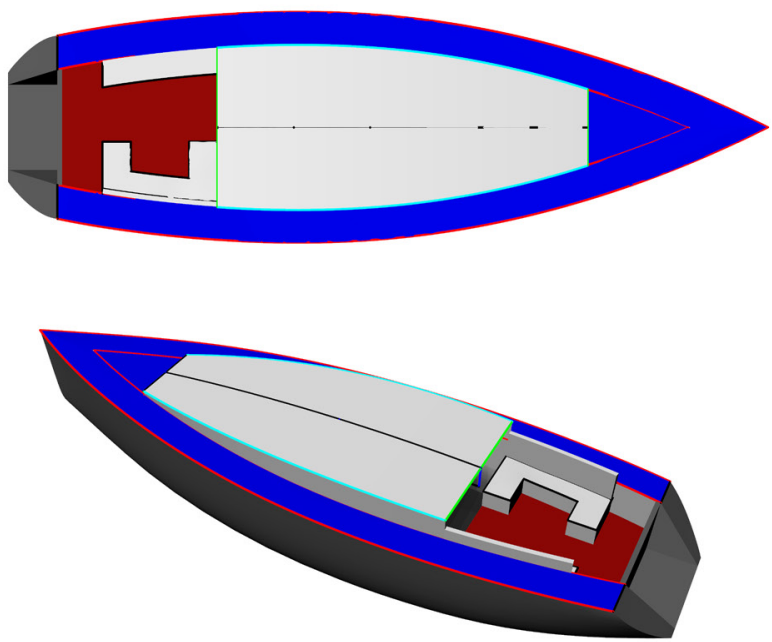
Figure: 22

Lower Deck Parameters General Arrangement Process (Data Suggested by Author).
Figure: 23

$2 d$ Lower Deck General Arrangement Process (Data Suggested by Author).

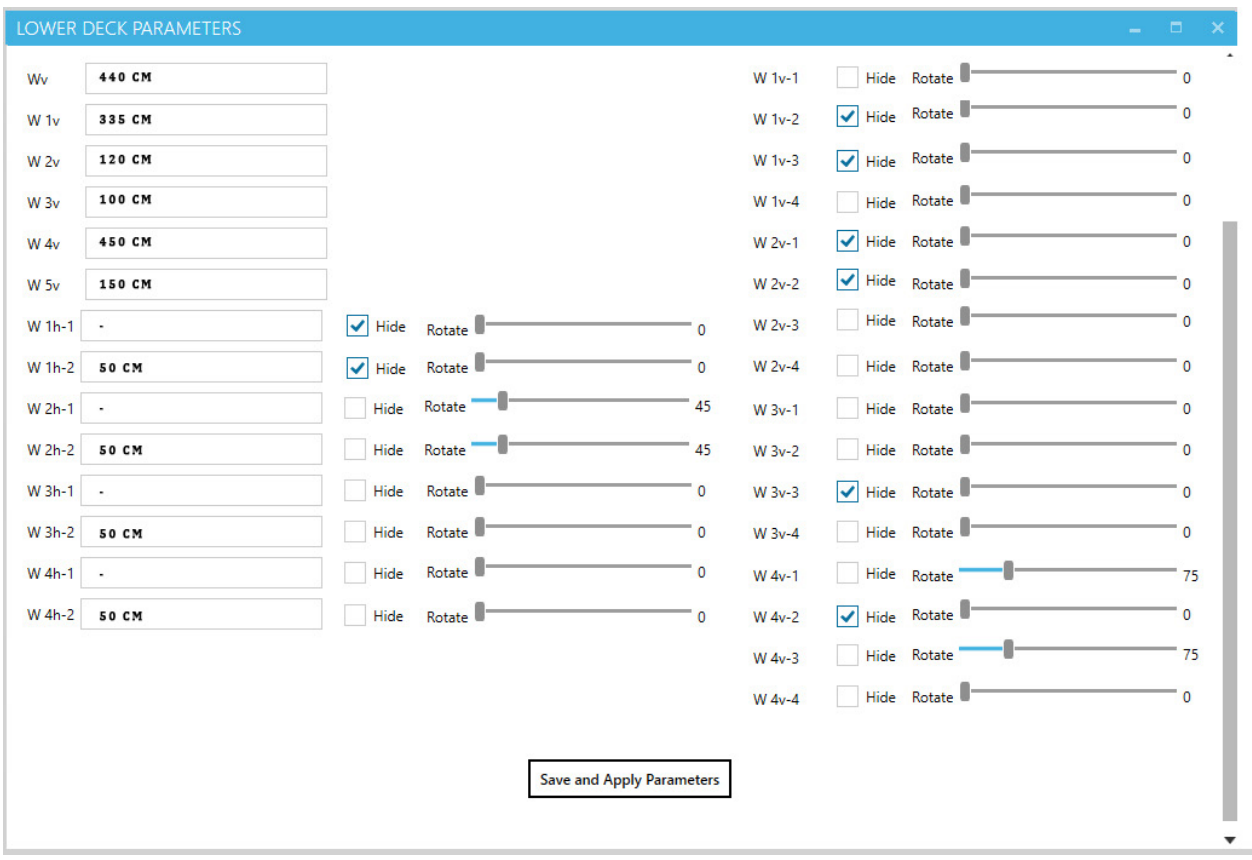

shows the general 3D layout of the yacht based on these parameters.

\section{Conclusion}

Yacht design is a special field that requires expertise. Academic education on this subject is recent, and naval engineers, architects, interior designers and industrial designers who are interested in this area have performed yacht design so far. This study proposes a quick and rough model for designers who want to work or are already working on yacht design.

In fact, the process of yachts design leads to standardization. Unique names are created for each of the spaces that constitute these vessels. There is almost nothing left after a vessel is dismantled according to the spatial characteristics of these names.

This study attempts to parameterize sailing yachts based on author's dissertation which examines the trawler typology (Özgel
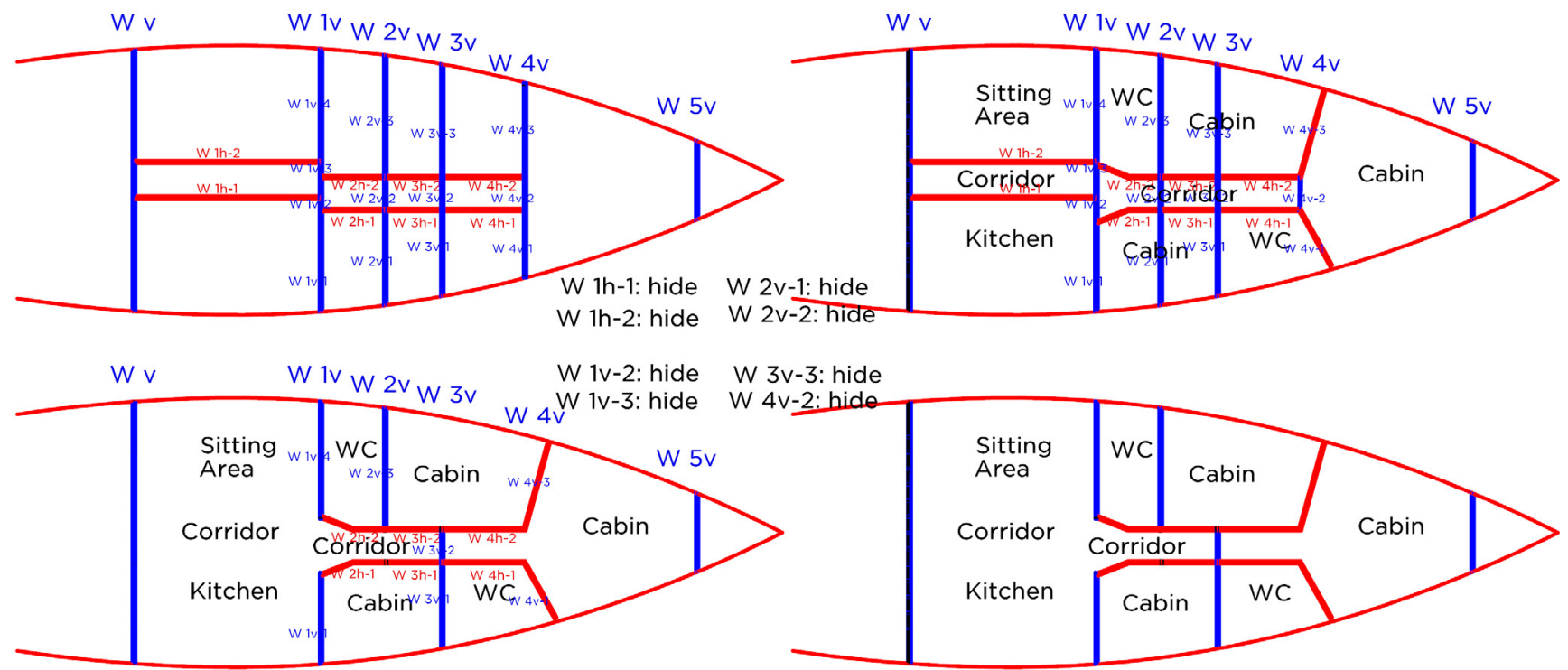

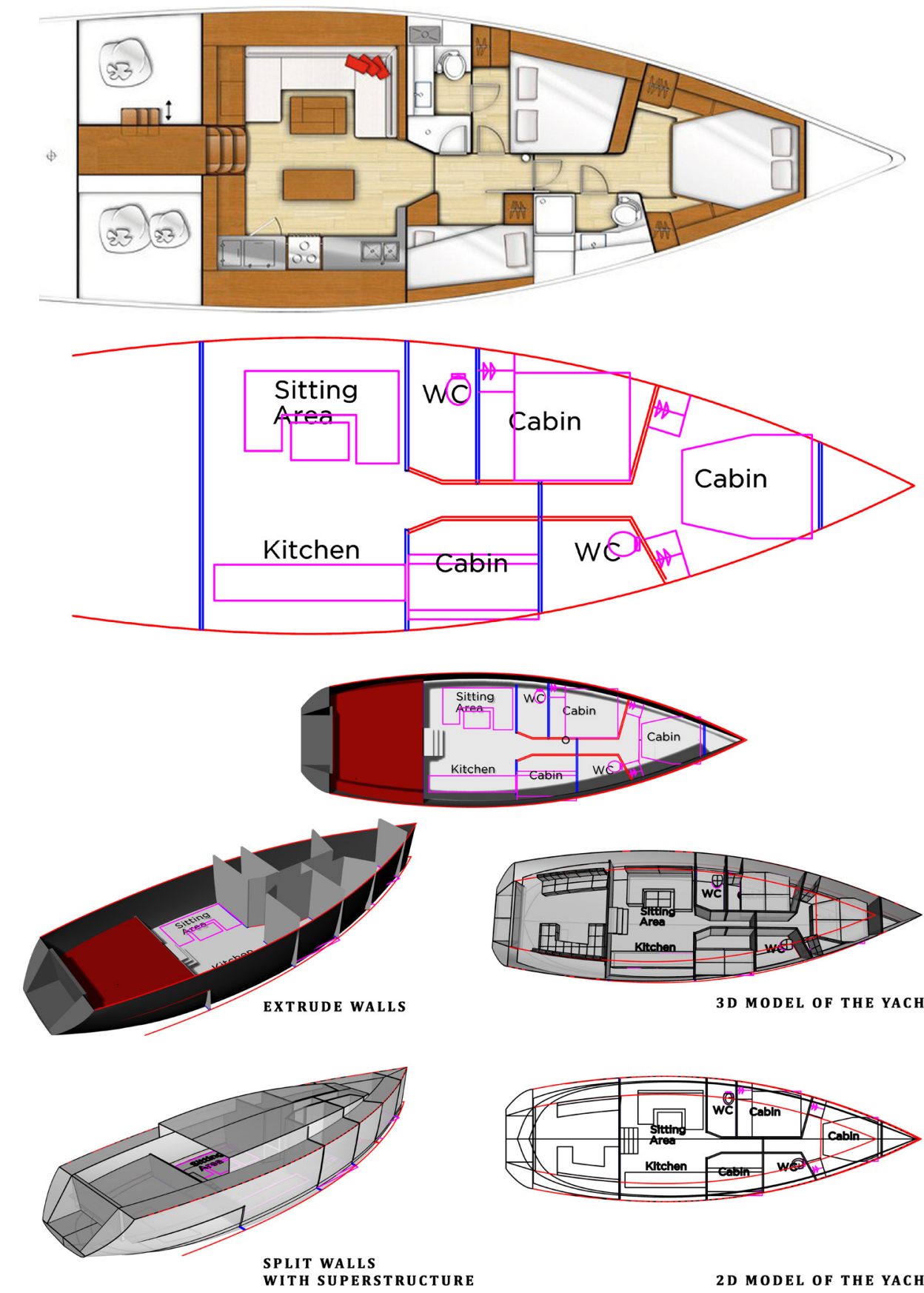

Felek, 2017). A model has been presented by identifying these spatial elements, revealing their relationship with each other, and quantitating the requirements of the typology. Thus, a rough model is revealed to guide those who are working or want to work in this area and the design process will be completed correctly by adding aesthetic values. The development of the

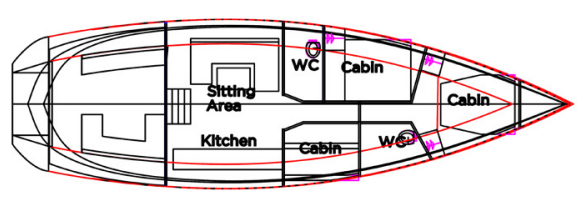

2D MODEL OF THE YACHT proposed model will be carried out with a group of people working in this area and it will be eliminated if there are any deficiencies or errors $\bullet$
Figure: 24

$2 d$ Lower Deck General Arrangement (Data Suggested by Author).

Figure: 25

Yacht Created by Model Proposal (Data suggested by Author). 


\section{References}

Bole, M. (1997). Parametric Generation of Yacht Hulls (Master Thesis, University of Strathclyde, Glasgow). Access address: https://www.polycad. co.uk/downloads/Parametric $\% 20$ Generation $\% 20$ of $\% 20$ Yacht $\% 20$ Hulls.pdf

Brower, K.S. and Walker, K.W. (1986). Ship Design Computer Programs - An Interpolative Technique. Naval Engineers Journal, 98, 74-87. doi:10.1111/j.1559-3584.1986.tb03417.x

Foster, I.T. (1979). Computer Aided Yacht Design in University of Canterbury (Research Project). Access address: https://ir.canterbury.ac.nz/bitstream/handle/10092/10118/foster_1979_report. pdf?sequence $=1 \&$ is Allowed $=y$

Göksel, M. A. (2006). Deniz Aracı Tasarımında İç Mimarlık Disiplininin Sınır Geçişleri ve Interdisipliner Görünümlerinin Değerlendirilmesi (Sanatta Yeterlilik tezi, Mimar Sinan Güzel Sanatlar Üniversitesi, İstanbul). Erișim adresi: http://tez.yok.gov.tr

Harries, S. and Detlef S. (1997, July). Numerical Investigation of a Systematic Model Series for the Design of Fast Monohulls (s 339-349) in Proceedings of the 4th International Conference on Fast Sea Transportation, edited by Delft University of Technology, Australia: Baird Publications

Harries, S. (1998). Parametric Design and Hydrodynamic Optimization of Ship Hull Forms. Germany: Berlin Mensch-und-Buch-Verl. Zugl.

Hollister, S. M. (1994). The Design Spiral for Computer Aided Boat Design. Accessed September 29, 2017. http://www.newavesys.com/spiral.htm.

Larsson, L. ve Rolf E. (2006). Yat Tasarımı Genel İlkeler (Yılmaz, T. Çev.) Türkiye: Birsen Yayınevi

Mancuso, A. (2006). Parametric Design of Sailing Hull Shapes. Ocean Engineering, 32 (2), 234-246. Doi 10.1016/j.oceaneng.2005.03.007.

Özgel Felek, S. (2017). 12-22 metre Trawler Tipolojisine Uygun Yat Güverte ve İç Mekanlarının Sayısal Olarak Otomatik Olușturulmasına Yönelik Model Önerisi. (Yayımlanmamıș doktora tezi) Mimar Sinan Güzel Sanatlar Üniversitesi, İstanbul

Pérez- Arribas, F., Suárez- Suárez, J.A and FernándezJambrina, L. (2006). Automatic Surface Modelling of a Ship Hull. Journal of ComputerAided Design, 38, 584-594. doi: 10.1016/j. cad.2006.01.013

Tokol, H. T. (2013). Okyanusașırı Uzunyol Yelkenli Gezi Yatlarında Yașam, Mekan ve Donanım İlișkisi. (Sanatta Yeterlilik tezi, Mimar Sinan Güzel Sanatlar Üniversitesi, İstanbul). Erișim adresi: http://tez.yok.gov.tr

Duman, İ. I. and Zengel, R. (2016). Effects of Physical Design Features to Human Comfort on Floating Spaces. Open House International, 41(1), 93-100. Access address: https:/www.researchgate.net/ publication/332950655_Effects_of_Physical_ Design_Features_to_Human_Comfort_on_ Floating_Spaces

URL-1: www. beneteau.com/en/sense/sense-51 [Accessed: 25 Feb 2017]. 